\title{
Iowa Stamp Scrip: Economic Experimentation in Iowa Communities during the Great Depression
}

\author{
JONATHAN WARNER
}

IN THE 1930s about 30 Iowa communities experimented with issuing scrip (a substitute for money) as a local means of combating the economic effects of the Great Depression. Sarah Elvins documented the use of scrip in Iowa from 1932 through $1934 .^{1}$ Here I will give a broader historical account of Iowa's experience with stamp scrip, with detailed accounts of some particular plans

1. Sarah Elvins, "Scrip Money and Slump Cures: Iowa's Experiments with Alternative Currency during the Great Depression," Annals of Iowa 64 (2005), 221-45.

I gratefully acknowledge a grant from the State Historical Society of Iowa that allowed this research to be completed. I am also grateful to Dordt College and the librarians there, particularly Dawn Van Den Hul, Interlibrary Loan Coordinator, who was somehow able to obtain the often obscure books and articles that I requested. Libraries, newspaper offices, and local history societies around Iowa were unfailingly helpful, providing access to archival material and explaining how to use a wonderful diversity of microfilm readers. Val Haverhals of Hawarden provided photocopies of many sections of the Hawarden papers, the Independent and Chronicle; and the Pella Chamber of Commerce gave me access to the minutes of their meetings from the 1930s, which greatly enriched the account of the trials of the local stamp scrip scheme. My wife, Lynda, deserves thanks for her forbearance during my many visits to small-town libraries and for proofreading. Marvin Bergman provided much encouragement and support, carefully reading drafts of the paper and cleaning up my tortured prose. And thanks go to Hugo Godschalk of Frankfurt, Germany, whose email to Dordt College got me started on this.

THE ANNALS OF IOWA 71 (Winter 2012). (C) The State Historical Society of Iowa, 2012. 
and projects. Delving into the details of a selection of stamp scrip projects not only shows the diversity of such plans and the results they achieved but also has relevance for today. Interest in local currencies has revived recently, and concerns about how to stimulate an economy stuck in recession have renewed interest in policies and proposals from the Great Depression. ${ }^{2}$

"Stamp money" is a particular form of scrip that required a special stamp to be affixed to the certificate each time it was used (or each week or month). The funds raised from the sale of stamps would accumulate and then be used to redeem the scrip. For this reason, stamp scrip is sometimes referred to as self-liquidating money.

Like many other suggestions of the time, stamp scrip arose as a response to the temporary problems caused by the Great Depression. After the boom years of World War I, the United States experienced a recession. For the urban areas of the country, it was a relatively short downturn, but for rural areas, recovery never really came. As the Roaring Twenties progressed, agricultural prices failed to return to their prewar highs. ${ }^{3}$ When the Depression hit and agricultural prices fell again, rural communities, including those in Iowa, faced further difficulties. Used to relying on their own resources, they sought local solutions to their problems. As the Depression took hold, people with debts lacked the means to pay them off. Money for poor relief dried up; tax revenues fell as farmers and those who relied on them defaulted on their taxes; banks found it hard to recoup loans, and then discovered that foreclosure meant big losses (especially when groups of farmers at the consequent auction intimidated potential bidders).

Could the tradition of self-help and concern about one's suffering neighbors produce a way out of the Depression? There

2. The transition towns movement (which seeks to increase sustainability of city living) sees community currencies as a means of encouraging economic localization and so reducing carbon emissions from transportation. Peter North, Local Money (London, 2010), provides a contemporary guide; the International Journal of Community Currency Research (at www.uea.ac.uk/env/ijccr/) has been recording developments in the field since 1997.

3. See, for example, John Fraser Hart, "Change in the Corn Belt," Geographical Review 76 (1986), 55 (fig. 3). 
was certainly no shortage of suggestions. Relief agencies solicited donations in kind, as well as asking for cash, but the size of the demands on local resources, even given their strict eligibility requirements, ${ }^{4}$ soon meant that funds were in very short supply.

By 1932, ideas on how to end the Depression abounded. John Norton of Suffield, Connecticut, thought that money should be backed by electricity production rather than gold. ${ }^{5}$ Frank G. Graham, a Princeton University economist, thought that the unemployed could be put back to work and paid in what they produced. ${ }^{6}$ A radio station in Norfolk, Nebraska, aired the possibility of issuing scrip to farmers in exchange for cutting their corn production. ${ }^{7}$ When the Iowa House and Senate convened after the 1932 election, members of the legislature, an Indianola newspaper reported, were "besieged with petitions, letters, telegrams and personal visitors proposing this and that thing - much of the suggestions resulting from radical and illadvised conversation on city street corners and rural meetings. What may be lightly said and suggested in places remote from the legislative halls may look foolish and puerile when considered from the hot-spot of legislative enactment." 8

Issuing scrip was just one option, but one that received, at least initially, substantial support. Scrip had been used in the financial panic of 1907, and merchants had often issued their own tokens. Stamp scrip had not been tried before, but seemed to be a way of stimulating business and providing for the unemployed. America's most noted economist of the time, Irving Fisher, produced a book advocating stamp scrip as a part of the solution to the nation's problems. ${ }^{9}$ Fisher wrote the book, he said, because as the idea spread rapidly across the country,

4. Only "deserving" unemployed men, resident in the city, generally qualified for relief. See Nancy E. Rose, Put to Work: Relief Programs in the Great Depression (New York, 1994), 17.

5. Madison (SD) Daily Leader, 12/30/1932.

6. Frank D. Graham, The Abolition of Unemployment (Princeton, NJ, 1932).

7. Norfolk Daily News, 1/11/1933.

8. Indianola Tribune, 2/7/1933.

9. Irving Fisher, Stamp Scrip (New York, 1933). Fisher's earlier (and more famous) work, Booms and Depressions (New York, 1932), includes an account of Silvio Gesell's stamped money plan (appendix 7, pp. 226-30). 
stamp scrip had become a "sensation."10 In February 1933 Congress even considered a bill for a national issue of stamp scrip. ${ }^{11}$ Much of the enthusiasm for stamp scrip came through news of the experiment in Hawarden, which briefly brought national (and even international) attention to that small town in northwest Iowa.

Stamp scrip existed in two "pure" forms. Transactions scrip required a stamp to be affixed every time someone used it. Because the first Iowa example, the Hawarden Plan, was of this form and was highly successful, most other Iowa issues were also of this type. By contrast, time-based stamp scrip required the stamp to be affixed at certain predetermined intervals, varying from three days to one month. Some communities issued a hybrid version - a stamp purchased for each transaction, or after so many days if it had not been used in the interim. Although small local plans could produce good results, experience suggests that neither the transactions stamp scrip that Charles Zylstra proposed for Hawarden nor the time-based version, originally conceived by Silvio Gesell and advocated by Fisher, was very successful. ${ }^{12}$ The hybrid version, however, did produce fair results where localities tried it, at least in Iowa.

Stamp scrip appealed to cash-strapped communities for a number of reasons. First, it looked as if it might provide a way out from the depths of the Depression by stimulating business and by providing the lacking medium of exchange. Second, it was a way for a community to provide sustenance for its unemployed and poor when no other avenue seemed to be open. And scrip appealed to the self-sufficiency ethos of many Iowa communities that preferred to rely on local action rather than wait to see what, if anything, might come out of Washington. Further, the self-liquidating nature of stamp money seemed to

\section{Fisher, Stamp Scrip, chap. 1.}

11. H.R. 14757, introduced February 22, 1933. See Ralph A. Mitchell and Neil Shafer, Standard Catalog of Depression Scrip of the United States - The 1930's including Canada and Mexico (Iola, WI, 1984), 311-13.

12. Silvio Gesell, Die Naturliche Wirtschaftsordnung (1916); translated into English by Philip Pye as The Natural Economic Order (Berlin-Frohnau, 1929); Fisher, Stamp Scrip, chap. 1, where he noted, "Stamp Scrip has two basic forms. And the one which happened to establish itself in this country as a precedent, is, in my opinion, the wrong one of the two." 
mean that all the projects would come to a natural end: when the scrip had finished circulating, the proceeds of the stamp sales redeemed the scrip.

Stamp scrip issues in Iowa ranged from the tiny (Humeston issued just 25 one-dollar certificates) to the overly ambitious (Polk County came to grief with a $\$ 125,000$ issue); from the successful (Keokuk, Hawarden, Rock Rapids, and several other small communities) to the disastrous (Polk County again). The initial Hawarden scrip issue is the best-known example, and Mason City's has been discussed before, ${ }^{13}$ but their experiences do not entirely represent what went on in towns and counties across the state.

In towns (and later counties) that decided to issue stamp scrip, a general pattern ensued: initial enthusiasm that communities, at last, had found a way of combating unemployment, then a period of disillusionment when the scrip circulated more slowly than anticipated. The issuer made appeals to get the stuff moving and to remind people to affix the stamp. Then came the development of an exit strategy: how to get the scrip out of circulation if no one seemed prepared to use it.

In most cases, municipalities used the scrip to pay unemployed family men to do a few days' work each week chopping wood, clearing vegetation from culverts, building roads, or engaging in other socially useful projects. Clearing snow became a popular use of labor in the especially hard winter of 1932-33. Des Moines used Polk County scrip to pay for some of the construction of its airport. Mason City's Globe-Gazette ran a competition to encourage readers to suggest suitable projects. A few cities used scrip to help farmers by buying corn or eggs at above the market price. ${ }^{14}$ This meant that salable commodities backed

13. See, for instance, Dan Buchan, "The Hawarden Script or Stamp Money," in Pot Pourri (Albert City, 1977). The plan merited a two-page account (by Don Leafstedt, relying on Buchan) in the town's centenary volume (1987). Hugo Godschalk, "Aufshwung durch lokales Nebengeld," Zeitschrift für Sozialökonomie 129 (2001), 11-16, includes a case study of Mason City. Elvins, "Scrip Money and Slump Cures," also makes reference to these examples.

14. Clear Lake used a "circulating check" rather than stamp scrip; Norfolk, Nebraska, used transactions stamp scrip but with only 35 two-cent stamps necessary for redemption; and Red Oak used 40 percent of its dated stamp scrip to purchase commodities. 
the scrip, thereby requiring less than a full dollar's worth of stamps to be sold in order to have sufficient funds to redeem the scrip.

Most issuers followed Hawarden's lead in issuing onedollar certificates. Some cities, though, preferred a 50-cent denomination. ${ }^{15}$ If, as was generally the case, customers received no (cash) change for their scrip, ${ }^{16}$ relatively large transactions had to be made; the smaller denomination then improved the rate of circulation of the scrip. Lake Mills used 20-cent certificates to pay unemployed transients to chop wood.17 There was, though, some fear that issuing fractional currency - denominations less than one dollar - was not strictly legal, but the authorities took no action against anyone in Iowa for doing so. ${ }^{18}$

Stamp scrip provided a helpful means of coping with some of the effects of the Depression for small towns in Iowa that met several conditions. The issue needed to be limited in size to prevent scrip "indigestion." Businesses had to be committed to the plan and take scrip as freely as they would accept cash. People with too much of the stuff needed a way to trade it in (a clearinghouse mechanism to overcome the problem of "congestion"). Finally, a reasonable exit plan was necessary. A few case studies illustrate how these conditions (or their absence) affected the relative success of stamp scrip experiments in Iowa communities. The case studies allow for the development of a more nuanced

15. A few places issued both $50 \$$ and $\$ 1$ denominations. Adel's first issue was of $\$ 1$ certificates, followed a few weeks later by $50 \$$ coupons. Very roughly, a dollar in 1932-33 would have the same purchasing power as somewhere between \$16 and \$18 in 2011 (see the inflation calculator at the Bureau of Labor Statistics' web site, www.bls.gov). Real wages are, of course, much higher today. Prevailing wages in Iowa for unskilled work were $20 \$-50 \$$ per hour, compared with around \$17 in 2010.

16. Some merchants would issue their own credit note for any remaining value; others would give change if the customer would pay for a second stamp. Either way, these practices constituted a disincentive to use the scrip.

17. Lake Mills Graphic, 3/22/1933. The scrip needed 20 one-cent stamps for redemption. Bowling Green, Kentucky, also issued 20\$ stamp scrip, but required 10 two-cent stamps to be affixed. Mitchell and Shafer, Catalog of Depression Scrip, 98.

18. The National Bank Act of 1864 provided for notes of $\$ 1$ and above, but not for fractional currency. Some people apparently came to believe that this in effect constituted a ban on the issue of fractional currency. 


\section{TABLE}

IOWA STAMP SCRIP ISSUERS

\begin{tabular}{|c|c|c|c|c|c|c|}
\hline $\begin{array}{l}\text { Town/ } \\
\text { County }\end{array}$ & $\begin{array}{c}\text { Date } \\
\text { started } \\
\text { (first } \\
\text { issue) }\end{array}$ & $\begin{array}{l}\text { Issue } \\
\text { denom }\end{array}$ & $\begin{array}{l}\text { (\$) and } \\
\text { ination }\end{array}$ & $\begin{array}{l}\text { Number } \\
\text { and } \\
\text { value of } \\
\text { stamps }\end{array}$ & Type & $\begin{array}{c}\text { Date } \\
\text { ended }\end{array}$ \\
\hline Hawarden & $10 / 8 / 32$ & 300 & $\$ 1$ & $36 \times 34$ & transaction & Jan 1936 \\
\hline $\begin{array}{l}\text { Rock } \\
\text { Rapids }\end{array}$ & $11 / 26 / 32$ & 250 & $50 \pitchfork$ & $54 \times 14$ & $\begin{array}{l}\text { hybrid: } \\
\text { week }\end{array}$ & Dec 1933 \\
\hline Eldora & $12 / 8 / 32$ & 285 & $\$ 1$ & $36 \times 34$ & transaction & Nov 1933 \\
\hline Lamoni & $12 / 8 / 32$ & 100 & $\$ 1$ & $36 \times 34$ & transaction & \\
\hline Sigourney & $12 / 8 / 32$ & 250 & $\$ 1$ & $36 \times 34$ & transaction & \\
\hline Albia & $12 / 21 / 32$ & $375+$ & 504 & $54 \times 14$ & transaction & \\
\hline Pella & $12 / 22 / 32$ & 500 & $\$ 1$ & $36 \times 34$ & transaction & June 1937 \\
\hline $\begin{array}{l}\text { New } \\
\text { London }\end{array}$ & $1 / 3 / 33$ & 100 & $\$ 1$ & $36 \times 34$ & transaction & \\
\hline Nevada & $1 / 5 / 33$ & 300 & $\$ 1$ & $36 \times 34$ & transaction & \\
\hline Grinnell & $1 / 10 / 33$ & 500 & $\$ 1$ & $36 \times 34$ & transaction & Nov 1933 \\
\hline Adel & $1 / 25 / 33$ & 300 & $\$ 1$ & $36 \times 34$ & transaction & Jan 1934 \\
\hline $\begin{array}{l}\text { What } \\
\text { Cheer }\end{array}$ & $1 / 27 / 33$ & 150 & $\$ 1$ & $36 \times 34$ & transaction & Jan 1936 \\
\hline Adel (2) & $2 / 8 / 33$ & 600 & 504 & $36 \times 1.54$ & dated: week & Jan 1934 \\
\hline $\begin{array}{l}\text { West } \\
\text { Burlington }\end{array}$ & $2 / 10 / 33$ & & $50 థ$ & $50 \times 14$ & transaction & \\
\hline Humeston & $2 / 11 / 33$ & 25 & $\$ 1$ & $54 \times 24$ & transaction & July 1933 \\
\hline Boone & $2 / 15 / 33$ & & $\$ 1$ & $36 \times 34$ & transaction & \\
\hline Centerville & $2 / 20 / 33$ & 600 & $50 థ$ & $54 \times 14$ & transaction & \\
\hline Lake Mills & $3 / 1 / 33$ & 300 & $\$ 1$ & $52 \times 24$ & transaction & Nov 1933 \\
\hline Greenfield & $3 / 11 / 33$ & 600 & 504 & $36 \times 1.54$ & transaction & Sept 1933 \\
\hline Red Oak & $3 / 11 / 33$ & 1000 & $\$ 1$ & $52 \times 24$ & dated: week & Nov 1933 \\
\hline Bedford & $3 / 13 / 33$ & 300 & $\$ 1$ & $50 \times 24$ & transaction & \\
\hline Lenox & $3 / 15 / 33$ & & 504 & $36 \times 1.5 \not$ & transaction & \\
\hline Pella (2) & $3 / 22 / 33$ & 1000 & $\$ 1$ & $50 \times 2 \$$ & transaction & June 1937 \\
\hline Keokuk & $3 / 27 / 33$ & 500 & $\$ 1$ & $36 \times 34$ & transaction & June 1933 \\
\hline Cass & $4 / 6 / 33$ & 4400 & $\$ 1$ & $50 \times 24$ & transaction & June 1935 \\
\hline Winneshiek & April 33 & 6000 & $\$ 1$ & $50 \times 24$ & transaction & Aug 1934 \\
\hline $\begin{array}{l}\text { Hawarden } \\
\text { (3) }\end{array}$ & $4 / 10 / 33$ & 300 & $\$ 1$ & $36 \times 34$ & time: month & May 1936 \\
\hline Earlham & $4 / 22 / 33$ & & 504 & $36 \times 1.54$ & transaction & \\
\hline Iowa City & $5 / 3 / 33$ & $1630+$ & & $50 \times 24$ & transaction & \\
\hline Polk & May 33 & 125,000 & $\$ 1$ & $50 \times 2 c$ & transaction & June 1934 \\
\hline $\begin{array}{l}\text { Mason } \\
\text { City }\end{array}$ & $5 / 6 / 33$ & 10,000 & $\$ 1$ & $52 \times 24$ & $\begin{array}{l}\text { hybrid: } \\
\text { week }\end{array}$ & June 1934 \\
\hline
\end{tabular}

SOURCE: Ralph A. Mitchell and Neil Shafer, Standard Catalog of Depression Scrip of the United States (Iola, WI, 1984), plus newspaper reports. There are also issues reported for Joice and a $20 \$$ second issue for Lake Mills, but no details are known. 
view of the stamp scrip experiments and may perhaps even offer a guide to best practices if the need ever arises for a selfliquidating form of community-based credit in the future.

THE STORY of stamp scrip in Iowa is inextricably linked with the name of Charles Zylstra of Hawarden. A prominent local businessman with political aspirations, he persuaded Hawarden's Chamber of Commerce and city council to adopt his plan. The world - in the guise of Yale economist Irving Fisher, numerous journalists, and even a Pathe News team - journeyed to Hawarden to see the scrip plan at work. As a result, this quiet little town on the Big Sioux River (pop. 2,459 in 1930) enjoyed its moment of fame. Letters arrived from as far away as Greece and Estonia asking for details of Zylstra's idea. Imitations appeared throughout Iowa and elsewhere in the United States. Zylstra was able to harness the publicity he received to secure election (as a Democrat in overwhelmingly Republican Sioux County, no less!) to the Iowa legislature in the November 1932 general election.

The Hawarden plan was not the first use of stamp scrip in the United States, however. The earliest use began several months earlier in Anaheim, California, where service station owner Joe Elliott launched his stamp scrip in January 1932. His "Anaheim Plan" was fairly widely reported at the time, and, as the Zylstra family had California connections, it is possible that Charles heard of it. ${ }^{19}$ Articles in Business Week, The Survey, and The New Republic over the summer of 1932 brought the idea of scrip to a wider audience. ${ }^{20}$ It is likely that Zylstra saw one or more of these articles - or, perhaps, given his Dutch ancestry,

19. On Anaheim, see Jonathan Warner, "The Anaheim Scrip Plan," Southern California Quarterly 90 (2008), 307-25.

20. "Unwilling to Give Relief, Congress May Offer to Lend It," Business Week, 3/9/1932, 16-18; Joanna C. Colcord, "The West Is Different," The Survey, 6/1/ 1932, 221; Hans Cohrssen, "Wara," The New Republic, 8/10/1932, 338-39. Irving Fisher read Cohrssen's New Republic article and recruited Cohrssen to become his assistant on research into stamp scrip. The New York Times had a brief account of the "Wara" stamp scrip the previous year: "Coal Mine Operator Issues His Own Money," New York Times, 3/29/1931. 
HOW STAMP SCRIP CIRCULATES

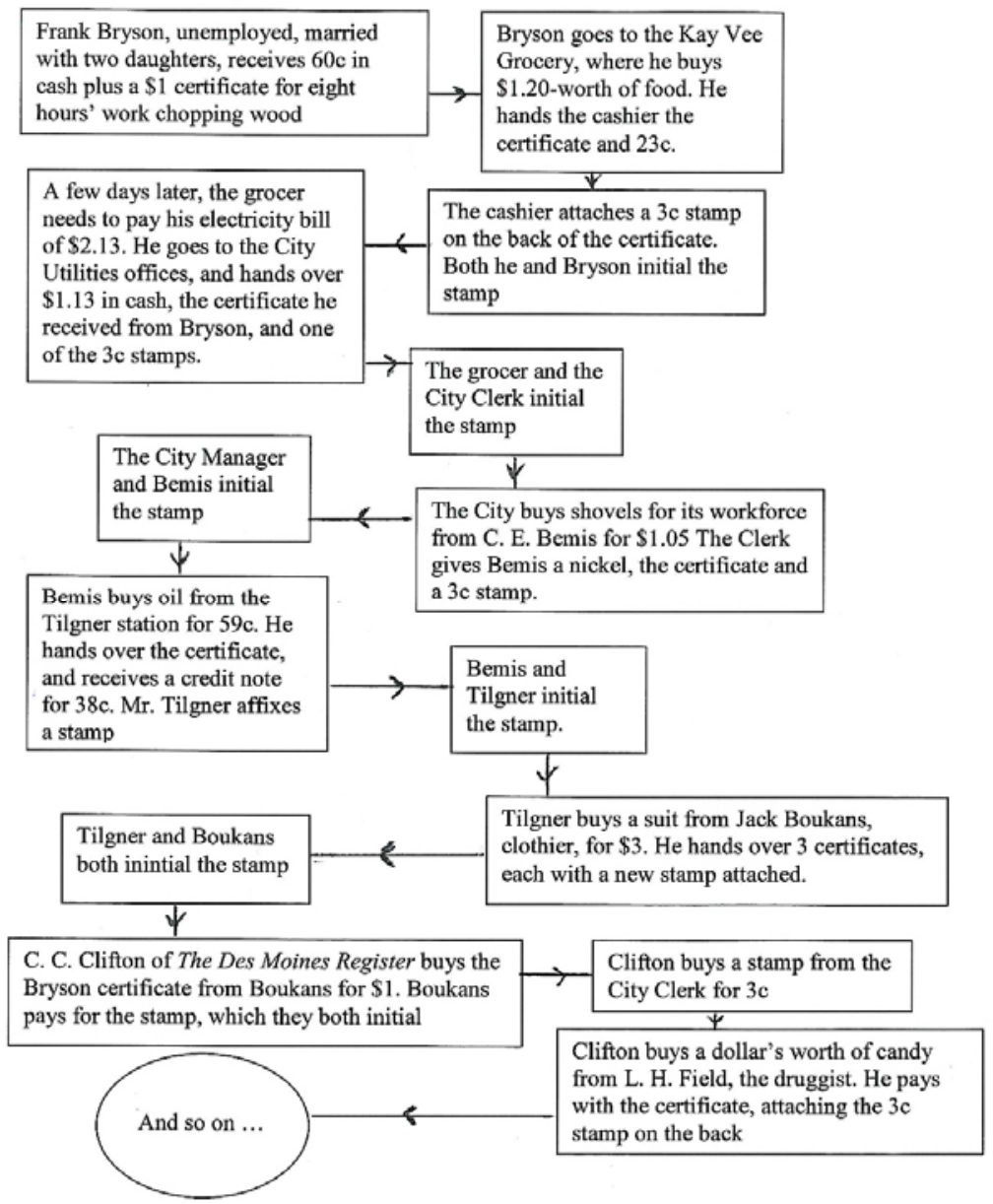

SOURCE: Des Moines Register, 12/4/1932, loosely based on the experiences of C. C. Clifton.

the piece in the Pella Chronicle suggesting something very similar to what became the Hawarden plan. ${ }^{21}$

Zylstra spent the summer of 1932 drumming up support for his idea, getting merchants and businesses in the town to sign a petition to the mayor and council. The petition called for the 


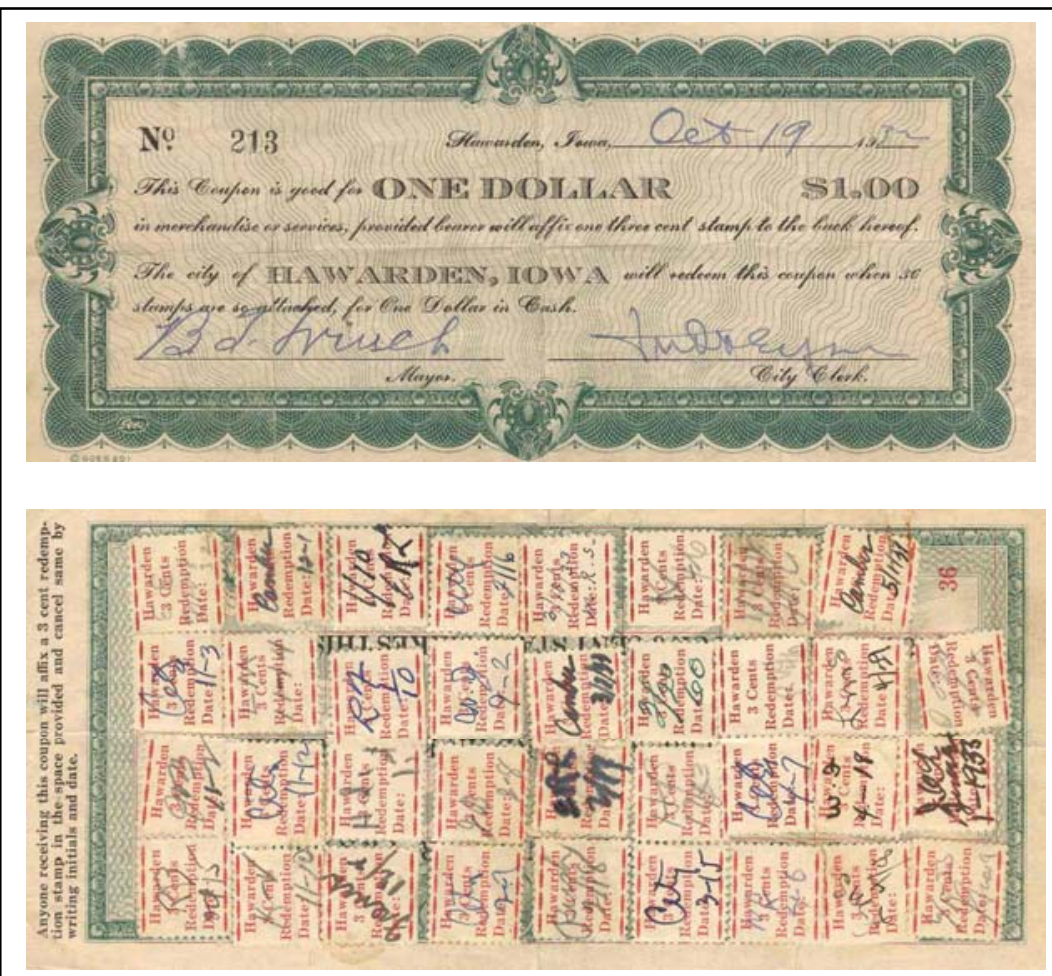

Front and back of a redeemed Hawarden stamp scrip certificate. From author's collection.

issuance of scrip to pay the unemployed to do work of social value in the community. Zylstra noted that for the plan to succeed, the whole community had to be behind the idea; businesses had to agree to accept the certificates, and other community members had to accept them as well. For businesses, he argued, the cost of the three-cent stamp to use the certificate was a good bargain: were it not for the certificate, the transaction would not take place at all, and three cents on the dollar was what a business might reasonably have to spend on advertising anyway. In addition, the backs of the certificates pointed out that they had come into circulation as a means of helping the unemployed, and, by generating business, would promote a return to prosperity. 


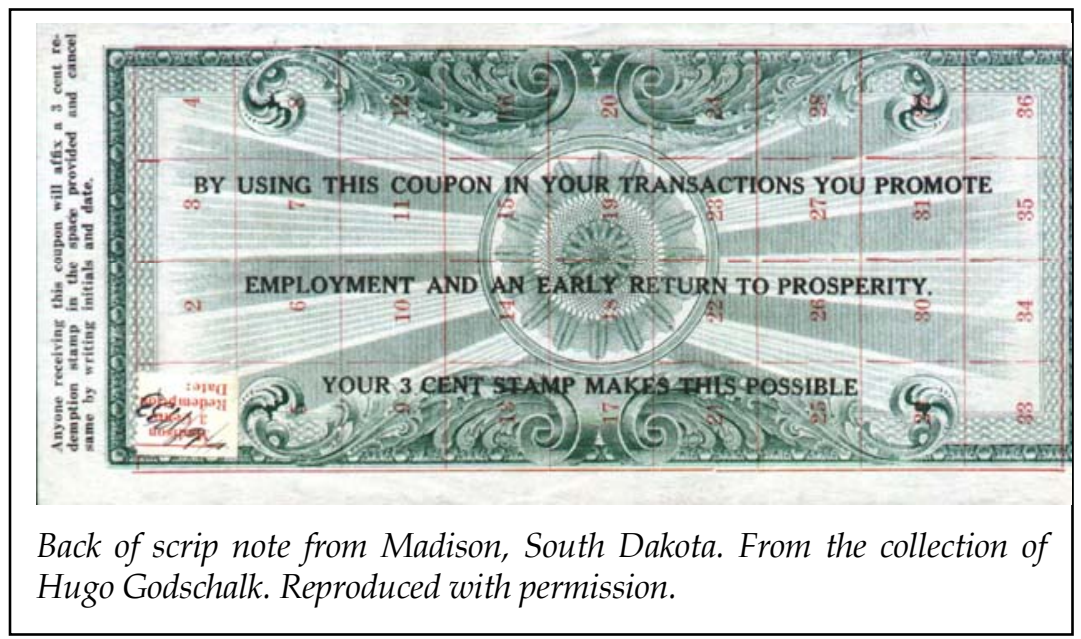

The Hawarden plan was launched in October 1932, when the first group of unemployed men (all heads of household) received $\$ 1.60$ for a day's labor on projects for the city. This sum comprised 60 cents in cash and a one-dollar scrip certificate that could be used in local stores to purchase groceries or other necessities. To be valid, the certificate needed to have a threecent stamp attached each time it was used.

The city clerk sold the stamps; anyone wanting to use scrip could buy them from his office. For the convenience of their customers, though, shopkeepers kept a stock of stamps on hand for use when customers presented certificates. The holder, then, would receive 97 cents worth of goods for the certificate (or a full dollar's worth if she produced the extra three cents for the stamp). When the certificate had 36 stamps on the back, the city office would redeem it for one dollar. The extra eight cents collected went towards advertising, printing, and administrative expenses.

The Hawarden plan was a marvelous success. A week after its launch, Irving Fisher heard about it as he was giving a lecture at Iowa State College in Ames. Fisher immediately abandoned his plans to travel on to Chicago and instead went to see for himself what was happening in Hawarden. Unfortunately, Zylstra was out of town on business when Fisher arrived, and the two 
never met, although they did exchange a number of letters over the ensuing weeks. ${ }^{22}$

Fisher's interest meant that the Hawarden plan received more than local attention. Reporters and the curious came to see for themselves: a long article in the Des Moines Register in early December brought the Hawarden experiment to the attention of other editors across the country and produced more visitors and a deluge of letters requesting details of the plan. For inquirers, Zylstra prepared a short booklet containing details of his idea and a selection of the articles that he had published in local papers. ${ }^{23}$ Delegations from other communities, such as Elk Point, South Dakota, made the pilgrimage to visit Hawarden. A Pathe news crew recruited local people to play the role of unemployed workers joyfully receiving their certificates. Zylstra also featured, opening some of the piles of mail that he had received. ${ }^{24}$ The newsreel was shown in movie theaters across the country, and more people wanted to learn about Hawarden's novel Depression-fighting idea. New York Post journalists Wayne Parrish and Wayne Weishaar visited Hawarden on their tour across the country to see how people were coping with the Depression. Their book, Men Without Money, published in early 1933, featured Hawarden in its first chapter, under the title "Hawarden

22. Hawarden Independent, 10/20/1932; Zylstra to Fisher, 10/28/1932 and $11 / 18 / 1932$, written in reply to letters from Fisher. Copies are in the Irving Fisher Papers, 1932-1938, in the New York Public Library.

23. Des Moines Register, 12/4/1932; Hawarden Independent, 12/15/1932. A copy of Zylstra's booklet is in the Fisher Archives. It contains a short set of directions for putting a scrip plan into operation (with the offer to supply 500 certificates, sufficient stamps, and 50 sheets of direction for \$25); three of Zylstra's newspaper articles ("Offers Plan to Issue Scrip," from the Le Mars Globe Post, 7/28/ 1932, the Hawarden Independent, 8/4/1932, and elsewhere; "More on Scrip," Hawarden Independent, 8/18/1932; and "Can Idle Men Cure the Depression," Sioux Center News, 9/29/1932); and an affirming report from the Hawarden Independent, 10/20/1932.

24. Hawarden Independent, 12/22/1932. Somewhat breathlessly, it reported: "Stark drama, rivalled perhaps only by that portrayed in 'Life Begins' will be unfolded in a Pathe news reel which is to be shown in hundreds of motion picture theatres throughout the nation, beginning tonight." 
Leads the Way." 25 The result: yet more people came to visit and letters continued to flood in. ${ }^{26}$

The publicity and large number of visitors probably guaranteed the success of the Hawarden plan. Most visitors spent money in the community and often took away one of the certificates as a souvenir. Those that visitors took never had to be redeemed by the city, so any stamps that were on them represented pure revenue for Hawarden. In addition, this reduced the number of certificates in circulation, and it is likely that those who visited and could not afford to buy a certificate to take home would at least buy and use one of them, thus speeding their circulation. Further, as Zylstra's plan became increasingly well known, the certificates became collectors' items. One numismatist offered to buy, at face value, all of the certificates after they had been redeemed. Thus the whole project would have cost the city absolutely nothing. ${ }^{27}$

IN THE MONTHS after Hawarden launched its scrip plan, towns around Iowa, but predominantly in southern Iowa, started similar projects. Most aimed at providing relief to the unemployed; a few used scrip to pay existing workers. Lenox's issue was to overcome an embarrassing funding gap when a court ordered the city council to pay to publish minutes of its meetings in the local paper. ${ }^{28}$

Interest increased further after February 1933, when the Iowa legislature passed the Zylstra Act, which authorized counties to issue stamp scrip. Towns that already had scrip found it particularly helpful if the local bank was closed, either through local problems (Humeston) or because of the nationwide bank holiday announced by President Roosevelt immediately after his

25. Wayne Weishaar and Wayne Parrish, Men without Money (New York, 1933).

26. Stamp scrip caught on in several other states. See, for example, Loren Gatch, “'This Is Not United States Currency': Oklahoma's Emergency Scrip Issues during the Banking Crisis of 1933," Chronicles of Oklahoma 82 (2004), 168-99.

27. Oddly, the city council refused the offer, preferring to sell the certificates individually. Hawarden Chronicle, 1/12/1933.

28. See report in the Lenox Time-Table, 2/23/1933. Publication of the minutes had been suspended as an economy measure; publishing the backlog would cost \$250 the city did not have. 
inauguration in March 1933.29 As one paper put it, when the local bank was forced to close,

Farmers have products to sell, the laboring man is willing to work, the manufacturers are ready to supply the needs and retail merchants have goods on their shelves with transportation facilities to move anything. There is no shortage in the country of anything except a medium of exchange to make it possible for one industry to exchange its goods for something. The monetary system has completely broken down. ${ }^{30}$

Another editor wryly noted, "Scrip money, which was not so popular a week ago, seems very much in demand now." 31

Unfortunately, the success of Hawarden's plan was not fully transferable as a model for relief of the poor or for stimulating local economies. Outside of Hawarden, the experience of the small Iowa towns that issued scrip was distinctly mixed. In all, nearly 30 cities and 3 counties in Iowa issued stamp scrip between 1932 and 1934. Towns with 1,500-3,000 people and small issues seemed to be more successful: greater "local patriotism" - what is now called social capital - was deemed to be the reason. Towns, such as Humeston, that had fewer than 1,000 residents and few businesses found the going tougher. Merrill (pop. 605 in 1930) was probably right not to issue stamp scrip. The town's city council thought that the costs of having the certificates and stamps prepared and paying royalties to Zylstra would make the whole thing uneconomical. ${ }^{32}$

In general, almost every town or county that issued scrip faced problems with slow circulation, congestion, and, after a

29. The disruption caused by temporary bank closures was felt more keenly in larger communities. In small towns, such as Hawarden, there was sufficient trust between buyers and sellers that business continued to be conducted by personal checks. Hawarden Independent, 3/9/1933. In larger cities, such as Des Moines, clearinghouse certificates backed by blocked deposits made a temporary appearance. Elsewhere, such as in Colfax, local businesses produced temporary notes. These were rapidly redeemed as soon as the banks reopened: all of the Colfax scrip was redeemed within a week of the local bank reopening in late May. Colfax Tribune, 3/9/1933, 5/25/1933, 6/1/1933.

30. New London Journal, 3/9/1933.

31. Sigourney Review, 3/8/1933.

32. Merrill Record, 1/5/1933. Zylstra charged $\$ 25$ for a kit containing 500 scrip certificates, 750 sheets of stamps, and 50 leaflets explaining how the plan worked. 
few months, the feeling that the scrip ought to be got rid of. This reaction is typical: "This script is circulating very slowly. Personally, I consider this plan was successful only in so far as it secured $\$ 300.00$ worth of immediate relief to the workers employed. As a business stimulator, I do not consider it is of much, if any, value." 33 The deficiencies of transaction stamp scrip are perhaps brought out most clearly in the case of Pella (pop. 3,326 in 1930).

THE PELLA Chamber of Commerce discussed the idea of issuing scrip on the Hawarden model in mid-December 1932. The result was an issue of $\$ 500$, half to be used by the city council and half to finance payment for public works via the Red Cross and other welfare organizations. The scrip, as in Hawarden, needed a three-cent stamp each time it was used and would be redeemed once 36 stamps had been affixed to the certificate. ${ }^{34}$ The first certificates were issued early in 1933. The local newspaper exhorted the citizens of Pella to

do their share in helping to carry the burden by informing his or her merchant that scrip will be accepted in change. ... [We] can't think of anyone who is not willing to donate three cents occasionally to give our unemployed work. In doing this, the purchaser will keep them from becoming objects of charity, which they do not want to be and which will be a greater drain on the community. There is no better way to solve our unemployment problem and, at the same time, contribute directly to the Welfare League than by accepting scrip. ... Now is the time for all to get in the spirit and keep the scrip moving in the direction of prosperity. Bring it around the corner to our very door and watch things happen for our good. We can, if we will. ${ }^{35}$

By early February the first issue of scrip had virtually all gone into circulation. The secretary of the Chamber of Commerce, Hugo Kuyper, wrote to Irving Fisher saying that things were going well, but that to ease the burden on the town's busi-

33. James L. Cameron, mayor of Eldora, Iowa, to Hans Cohrssen, 2/13/1933, Fisher Archives.

34. Pella Chronicle, 12/15/1932.

35. Pella Chronicle, 1/5/1933. 
nesses the general public needed to be educated to accept the scrip. Kuyper thought that would be an uphill job and asked Fisher for suggestions on how to do so. ${ }^{36}$

Kuyper indicated that the Chamber was considering a further issue of scrip. A visit from Zylstra, plus the enthusiasm of Earl Black of Black's Style Shoppe, who said it had been easy for him to pass on scrip he'd received, led to a vote to issue another $\$ 1,000$ worth of scrip. The following week the Chamber resolved that the new issue would be a transaction stamp scrip, requiring 50 two-cent stamps for redemption. Zylstra received $\$ 25.63$ for his visit and for providing the certificates. ${ }^{37}$

At first all went well. The local newspaper thought that the new issue came at an opportune time, as the Pella banks remained closed. ${ }^{38}$ By the fall of 1933, though, problems, especially congestion, were coming to the fore. Although the Chamber had arranged to set up a clearinghouse, scrip was tending to pile up there. Many merchants were willing to sell scrip to the clearinghouse for 96 cents, but few people wanted to buy it for 97 cents, despite Zylstra's predictions. He was on record as saying that the amount of scrip that would come back through the banks would be small. "With American salesmanship what it is, Mr. Zylstra is counting on the circumstance that as between selling a dollar's worth of goods and making a profit or simply cashing scrip at 96 cents as an accommodation, merchants are going to sell goods. 'Normal self-interest,' he said, 'will make the merchant see the advantage of selling goods.' " 39

But it wasn't happening that way. For the first time, the Chronicle struck a negative note. "We have scrip. What are we going to do with it to get it out of circulation? . . . The issue has moved so slowly that many are becoming impatient over it and asking, 'When will the end be? When will the issue be redeemed?'

36. Minutes, Pella Chamber of Commerce, 2/9/1933, Pella Chamber of Commerce Archives, Pella; Kuyper to Fisher, 2/14/1933, Fisher Archives.

37. Pella Chronicle, 3/16/1933; Minutes, Pella Chamber of Commerce, 3/16/ 1933, 4/18/1934. The Scrip Committee had deadlocked over whether transactions or dated stamp scrip were the more appropriate type.

38. Pella Chronicle, 3/30/1933.

39. Minutes, Pella Chamber of Commerce, 9/18/1933, 9/21/1933; New York Herald Tribune, 2/26/1933. 
... A comparatively small number of notes have been redeemed to date. Whose fault it is, we don't know. But somebody is loafing on the job." 40

That "somebody" continued to loaf. The Chamber tried a number of tactics to reduce the volume of notes, estimated at $\$ 1,000$ worth, held by the clearinghouse: it reduced the purchase price to 94 cents and the sale price to 96 cents plus the two-cent stamp. ${ }^{41}$ In addition, it sold nearly redeemed scrip at 99 cents on the dollar, with no stamp needed for the first transaction. The Chronicle struggled to understand why the scrip was not circulating.

What is it about scrip, stamp notes that makes them unacceptable to the public and some of our merchants? A business man remarks that everyone should be glad that we have scrip and he wonders what the result would be if we did not have it, what would take its place, with so little money in circulation. ... As things are, it is far better to have $\$ 1000$ or $\$ 2000$ in stamp notes circulating than to not have that medium of exchange. Everybody ought to co-operate in the scrip campaign, buy it, stamp it, buy with it and keep it moving. Why not, when 50 cents can be saved on every $\$ 25.00$ purchase? ${ }^{42}$

But, of course, that was not how the people of Pella saw it. As circulation of the scrip continued to be very slow, the Chamber began to discuss ways of winding up the project. The Chronicle suggested a bond issue; others wanted to reduce the number of notes by replacing the scrip issue with a new one to represent the amount still outstanding. The Chamber made no progress, and the mayor complained that merchants seemed to be using the scrip only to pay their bills to the city. Ultimately, the city responded by refusing to accept scrip for the payment of utility bills, to the chagrin of the Chamber. The Stamp Note Committee, refreshed with new members in August 1935, had to devise a

40. Pella Chronicle, 10/5/1933. In fact, no notes of the second issue had yet been redeemed. The first, presented for payment by the still optimistic Earl Black, came in in mid-October. Pella Chronicle, 10/19/1933.

41. Minutes, Pella Chamber of Commerce Board of Directors, 11/8/1933; Pella Chronicle, 11/16/1933. Kuyper reported that the city held most of the remaining $\$ 500$ of the scrip, so the amount still in circulation was tiny.

42. Pella Chronicle, 11/23/1933. 
plan to redeem the remaining scrip. Again, they made no significant progress. 43

The Pella scrip, copying Hawarden, had printed on it the expiration date of January 1, 1936. But, as the Chronicle noted, that did not mean that the scrip became redeemable on that date: the notes remained in circulation. A suggestion was made that merchants pay farmers in scrip at more than the market price for chickens and eggs. "This idea met with enthusiastic response, but action was postponed." A count turned up 361 notes still in circulation; the Stamp Note Committee thought that up to another 200 could still be stashed away somewhere. ${ }^{44}$

Another audit of the scrip still in circulation in July 1936 revealed a total of 625 notes still unredeemed. The Chamber seemed unable to devise a plan to bring the project to a conclusion. Although it agreed that the issue should be replaced by a new dated scrip issue requiring a weekly stamp, nothing came of the suggestion. ${ }^{45}$ Frustration grew. Some members of the Chamber refused to pay their dues until the scrip issue was resolved, and, because the date of redemption was past, many no longer felt any obligation to circulate it further. After much discussion, Chamber members voted to replace the old committee with a new one, with instructions to "hop to it." 46

43. Pella Chronicle, 5/10/1934, 6/21/1934; Minutes, Pella Chamber of Commerce Board of Directors, 11/28/1934, 7/8/1935, 8/29/1935; Minutes, Pella Chamber of Commerce, 5/10/1934, 7/11/1935, 9/12/1935. In the run-up to Christmas, shoppers received a lottery ticket for each $25 \$$ of purchase, with winners drawn on three consecutive Saturdays. Minutes, Pella Chamber of Commerce, 11/19/ 1935. The winners' prizes were paid in scrip, with $\$ 100$ worth allocated for that purpose. The Chamber thanked the Chronicle for its help with publicizing this and printing the tickets for free. The net cost to the Chamber was $\$ 35.50$. Minutes, Pella Chamber of Commerce Board of Directors, 1/1/1936.

44. Minutes, Pella Chamber of Commerce Board of Directors, 1/1/1936; Pella Chronicle, 1/1/1936, 1/19/1936, 1/23/1936. The estimates of outstanding notes seem to have been overly conservative.

45. Minutes, Pella Chamber of Commerce Board of Directors, 6/18/1936; Minutes, Pella Chamber of Commerce, 6/25/1936. Two months later the Chamber countermanded the decision to issue dated scrip "in view of the fact that [the committee] had made no progress." Minutes, Pella Chamber of Commerce, 8/27/1936.

46. Pella Chronicle, 9/3/1936. See also the Pella Chamber of Commerce's newsletter, The Informer, undated (probably early September, 1936), Pella Chamber of Commerce Archives. 
But the new committee had no more success than the old one. It ordered a canvass of the amount of outstanding scrip in September 1936, but nothing happened as a result. Not until eight months later, following another canvass, did the Chamber take any serious action. It solicited donations from its members to redeem the outstanding notes. The Chamber told the public to turn in the remaining scrip certificates by June 14 for a receipt, which would be paid in cash as soon as the necessary donations had been received. ${ }^{47}$

It was necessary to solicit further donations, but the miracle happened.

There is general rejoicing around Pella that the stamp notes or scrip are in the process of being retired. This form of exchange came into being when the depression was at its height, and it served a good purpose. It may be said here though that there never was 100 per cent co-operation and not all the rules of compliance were carried out. There is no question that there were hundreds of transactions without attaching the required stamp which naturally slowed up circulation. The date of retirement having arrived, some merchants refused to accept scrip. This made it embarrassing to the holder of stamp notes. Merchants with the largest volume of city business got the worst end of the bargain and were literally loaded down with scrip. Then, too, the scrip seemed to move around in a circle, going from one concern to the other and back again. It is well that the chamber of commerce has taken steps to retire it.

And so the longest-lived stamp scrip project in Iowa finally came to an end. The Chronicle wrote that, locally, nothing had "so befuddled the minds of people as the stamp notes." 48

GIVEN PELLA'S EXPERIENCE, one might predict that bigger stamp scrip issues were unlikely to succeed, especially if communities chose Zylstra's transactions scrip. The county scrip issued in 1933-34 provides a test of this hypothesis.

47. Minutes, Pella Chamber of Commerce Board of Directors, 9/15/1936, 5/27/1937; Pella Chronicle, 6/3/1937.

48. Minutes, Pella Chamber of Commerce Board of Directors, 6/10/1937; Pella Chronicle, 6/10/1937, 7/16/1937. See also The Informer, undated (probably early June 1937). 
Scrip enthusiasts in Hawarden mooted the idea of extending stamp scrip to counties soon after the launch of the Hawarden plan. The Hawarden Chamber of Commerce approached the Sioux County supervisors in November 1932. Although the supervisors rejected any issue of scrip, Zylstra's friends continued to advocate for it around the county. ${ }^{49}$

Charles Zylstra himself was an ambitious man. As many ambitious men had done before him, he chose to go into politics, comfortably winning the Sioux County seat in the Iowa House in November 1932 - the first Democrat to win in Sioux County since the late nineteenth century. ${ }^{50}$

When the Iowa legislature convened in early January 1933, Zylstra brought forward a bill to allow counties to issue scrip as a means of poor relief. His idea intrigued his fellow legislators, and reaction was generally supportive. The act proposed to give the board of supervisors of a county the option of introducing scrip if 2 percent of voters or 51 percent of merchants in the county asked for it. 51

Under the county plans, 50 two-cent stamps had to be affixed to the scrip for redemption. ${ }^{52}$ Banks had the right to accept the stamp notes in amounts of $\$ 25$ or greater, for 96 cents per dollar note in cash, and had no obligation to affix a stamp (marking the last stamp "cashed" to explain the break in initials). They could then pass the notes on to their customers at 97 cents. In exchange for this new revenue source, the act required banks to keep a stock of the redemption stamps to sell to their customers. Banks could also turn in scrip to the county treasurer at 97 cents; this discount was supposed to cover printing and other administrative costs. Having received back the scrip, the county could then use it instead of cash to pay county and school district employees.

49. Alton Democrat, 11/18/1932, 11/25/1932; Sioux County Index, 12/23/1932.

50. Initially he was thought to be the first ever; then an Alton pioneer alerted the Alton Democrat (11/18/1932) to the election of a Democrat back in 1891.

51. Laws of Iowa, 1933, chap. 103, pp. 129-30, where the law is identified as "An Act to provide a plan for the relief of poor and unemployed people." See also, for example, the Corydon Times-Republican, 2/2/1933, syndicated to other newspapers in south-central Iowa.

52. It was argued that $3 \$$ was too much, given the low rate of profit for many businesses at the time. See a letter from a Hawarden official to J. J. McManus, Winneshiek County Board of Supervisors, in Decorah Journal, 2/28/1933. 
Further provisions of the act required minimum pay rates (25 cents per hour) for work carried out for scrip and specified who was eligible for work under the plan. Counties had the right to use the stamp note plan as a substitute for all other forms of poor relief. The state would print the notes and provide them to the counties at cost; Zylstra agreed to forgo any royalties and to surrender his copyright on scrip to the state. ${ }^{53}$

The bill received bipartisan support in both the House and the Senate and passed with over 80 percent approval. "One senator called up a store in Hawarden at random and asked the merchant what he thought of the scrip money plan. The merchant replied enthusiastically that it was working out splendidly in every respect. Upon reporting his telephone call and the result, the senate took up action on the bill and adopted it without delay." 54

But all was not sweetness and light. The Hawarden Independent had turned against the idea of scrip. Its editor, Merle Stone, wrote that the bill had been rushed through the legislature (the fact that the House gave it overwhelming support served only to demonstrate, in Stone's opinion, that few members had read it) and was highly defective. Although Hawarden had benefited from the publicity resulting from its issue, that would not be the case generally for all communities. In fact, this "unsound scheme ... has already gone through the experimental stage and found sadly wanting." Stone complained specifically that the bill did not define "established merchants"; those who would seldom see a single scrip certificate could cheerfully petition for an issue, knowing that they would avoid the costs. He added that a scrip issue under the bill would prevent the county from making any tax levy for poor relief; and that many businesses, particularly chain stores, non-local utility companies, and railroads, would refuse to accept the scrip and so avoid the costs. He concluded, "It seems little short of amazing that a legislative body in Iowa should 'fall' for it." 55

53. Laws of Iowa, 1933, chap. 103, pp. 129-30. As the county scrip notes bear Zylstra's copyright notice, this appears not to have happened; but he did waive the right to receive any payment from the state for the county scrip notes.

54. Alton Democrat, 3/3/1933.

55. Hawarden Independent, 2/23/1933. 
But fall for it they did, perhaps concluding, along with more Democrat-leaning newspapers, that a prophet is without honor only within his home district. ${ }^{56}$ Zylstra's bill was signed into law on February 28, 1933.57 Within a week, Franklin Roosevelt had been inaugurated as president and had declared a nationwide bank holiday, surely a wonderful opportunity to try scrip. But the act seemed to be badly worded and imprecise; although it was to be in operation for only two years, within twelve months it produced at least three court cases and a bill to repeal it.

In a number of counties, organizations representing the unemployed lobbied hard for the issue of scrip and managed to amass the signatures of 2 percent of the electorate. Getting the support of 51 percent of a county's businesses was far more difficult. Despite the efforts of Zylstra and Sioux County Senator G. E. Roelofs, who organized a rally in support of scrip in Orange City (the Sioux County seat) in early March, the Sioux County Board of Supervisors trod carefully; after consulting with merchants from the county's towns and hearing from Merle Stone about the problems of circulation, they decided against it. 58 They were probably wise to do so: Where support for scrip was not wholehearted, disaster was likely, as the issue in Polk County and the battle over issuing it in Pottawattamie County both demonstrate.

Charles Zylstra visited Pottawattamie County in April 1933 to whip up support for an issue. He acknowledged that scrip was proving unpopular in places where Reconstruction Finance Corporation (RFC) funds were flowing freely but claimed that it was well received by businessmen where cash was in short supply. Initially, the county supervisors unanimously rejected the idea of issuing scrip; then they revisited the issue but, to the chagrin of 300 unemployed people crowding the lawn outside

56. See reports on the bill's passing in the Sioux Center News, 3/2/1933, and the Alton Democrat, 3/3/1933.

57. Laws of Iowa, 1933, chap. 103, pp. 129-30. The full text was also published in the Hawarden Chronicle and the Boyden Reporter, 3/9/1933.

58. Alton Democrat, 3/10/1933; Minutes, Sioux County Board of Supervisors, 3/9/1933, 3/16/1933. Merle Stone's editorial in the Hawarden Independent, 2/23/1933, probably influenced their decision. 
the courthouse, insisted on demonstrated support from merchants. ${ }^{59}$ The county Public Welfare Union (PWU) duly collected merchants' signatures and presented them to the supervisors. Roy Harrop of the PWU predicted that if scrip were not issued the unemployed people waiting for scrip-financed work would break into stores to get food to eat. "I am not making any threats but from the mood of that mob out in front you will have to bring the militia inside of a week," he declared. Cowed, the board of supervisors decided to go ahead and issue $\$ 10,000$ in scrip. But setting up the required County Stamp Note Committee proved challenging, as no one wanted to serve. When the board failed to ask his preferred candidate, Harrop thanked the council for the "beautiful slap in the face." In any case, opposition from a group of merchants led the committee to decide not to issue any scrip after all. Frustrated, the PWU sued the Stamp Note Committee to compel it to issue scrip. ${ }^{60}$ When the lawsuit failed, Harrop considered an appeal to the state supreme court, but then finally realized the hopelessness of the case. And so Pottawattamie County never used stamp scrip.

IN VIEW of Polk County's trauma with county scrip, Pottawattamie County should perhaps have counted its blessings in having to deal only with Mr. Harrop. Polk, the most populous of Iowa's 99 counties, hosted the largest county stamp scrip issue in Iowa. At the start of the bank holiday, County Supervisor E. R. Bennett announced that Polk County was prepared to issue scrip under the Zylstra bill, if necessary. By the end of the month, enough merchants had given the necessary assurances, and 50,000 certificates were ordered, out of the $\$ 175,000$ that Polk County was entitled to issue. According to Charles Saverucle, president of the Home-Owned Business Association, more than 1,400 Des Moines businesses, representing 80 percent

59. Council Bluffs Nonpareil, 5/1/1933, 5/15/1933, 6/2/1933; Minutes, Pottawattamie County Board of Supervisors, 5/25/1933 and 6/2/1933, as published in the Avoca Journal-Herald, 5/25/1933; Minutes, Pottawattamie County Board of Supervisors, 6/2/1933, as published in the Avoca Journal-Herald, 6/8/1933.

60. Council Bluffs Nonpareil, 6/15/1933, 6/16/1933, 6/17/1933, 6/28/1933, 7/4/1933; Minutes, Pottawattamie County Board of Supervisors, 6/16/1933, as published in the Avoca Journal-Herald, 7/6/1933. 
of wholesalers, jobbers, and retailers, had agreed to accept the scrip. ${ }^{61}$

But there was also plenty of opposition. The president of the Iowa State Federation of Labor, J. C. Lewis, argued before the Des Moines City Council that "every American wage earner should be paid in cash," as workers on relief projects being paid in scrip were earning only just over half the union wage. Fifty members of the Retail Merchants Bureau who had originally signed on now said that they would not accept scrip as long as RFC funds were available to pay for work by the unemployed. The League of Unemployed failed in a legal attempt to prevent any further use of scrip by the city; the court said that it lacked standing to bring such an action. ${ }^{62}$

But over the next several months requests for scrip came from the city council for several purposes: to clean up rubbish dumps $(\$ 1,500)$, to grade roads $(\$ 2,000)$, to install a swimming pool $(\$ 1,000)$, and to build a hangar at the city airport. Polk County decided to use $\$ 3,000$ of "recycled" certificates to pay county employees. Those certificates could be bought from banks for 97 cents, thus saving the county one cent on each dollar, even after it had affixed the two-cent stamp. Five percent of county merchandise warrants were paid in scrip. ${ }^{63}$

By mid-October, Polk County had issued $\$ 125,000$ of scrip, but only one note had been submitted for redemption (and that had been rushed through the required 50 transactions as an exercise by a group of young East Des Moines businessmen). ${ }^{64}$ Only $\$ 11,000$ of stamps had been sold. Scrip proponents pointed out that as long as the stamp notes were out circulating, they were working. One problem seemed to be that merchants preferred to keep the scrip until they had \$25 and then cash it at the bank rather than trying to use it or embarrassing their customers by giving it out in change. 65

61. Des Moines Tribune, 3/4/1933, 3/29/1933.

62. Des Moines Tribune, 5/1/1933, 5/3/1933.

63. Des Moines Tribune, 7/6/1933, 7/20/1933, 7/29/1933; Des Moines Register, 8/3/1933.

64. Another note was brought in to the redemption office - but at the last minute, the holder decided to keep it as a souvenir.

65. Des Moines Register, 10/16/1933. 
The scrip was becoming a frustration to businesses. In September R. W. Schaub, a Des Moines builder, filed suit against the Polk County Board of Supervisors and others, arguing that the Zylstra Act violated both the U.S. and Iowa constitutions by purporting to allow the emission of bills of credit as a form of legal tender, powers that are reserved for the state and federal governments. He ended his 15-point indictment with a couple of catch-all complaints:

14. That the act is illegal because the scrip is "spurious and contrary to all sound principles of banking, is fiat and bogus money and not legal tender, neither is it a specific promise to pay on a certain date nor by any party or parties legally bound to pay."

15. That the act's language is indefinite, and that the act is economically unsound and "contrary to all sound business principles." 66

Although the case was postponed indefinitely, the writing was on the wall.

At the start of the 1933-34 special legislative session, state senator George A. Wilson of Des Moines introduced a bill to wind up the use of stamp scrip by counties, requiring them to issue bonds to redeem the scrip. Wilson argued that scrip had proven to be a costly experiment and that Polk County, at least, was anxious to divorce itself from it as quickly as possible. ${ }^{67}$ Once the mandating "must" redeem the scrip was changed to a permissive authorizing "may," even Zylstra supported the bill.

Polk County was now able to redeem its scrip, but it took a considerable loss in the process. A bond issue takes a while to prepare; meanwhile, scrip was piling up in the Des Moines treasurer's office. The county paid its workers with some, and each month the city would try to pay half of its water bill in scrip, but each time the water board refused to accept the scrip and returned it. By early March 1934, \$7,762 in returned scrip was held by the city, stored bundled in newspaper in the treasurer's office. Once the supervisors had approved the bond issue for redemption, scrip received by the treasurer's office was stamped "canceled" and then given back to the holder to circulate with-

66. Des Moines Register, 9/10/1933.

67. Sioux City Journal, 12/30/1933. 
out the need for more stamps. Having received authorization to redeem the issue, the treasurer announced that, starting April 16, the canceled scrip would be exchangeable for cash. ${ }^{68}$ By the end of May, it was all over, to everyone's relief.

Was it, then, impossible that county scrip could work? The more modest issue in Cass County (along with Winneshiek, the only other counties to ask for scrip under the 1933 act) suggests that problems might be no greater than with municipal issues.

CASS COUNTY was interested in issuing scrip. The County Poor Fund was effectively insolvent after a Des Moines company, citing the "unsettled financial conditions," pulled out of a deal to take up $\$ 32,500$ of the county's warrants. ${ }^{69}$ The board of supervisors had received a petition, signed by more than the required 51 percent of the county's established merchants, suggesting widespread support. The board voted 4-1 on Monday, March 6 (the first working day of the Roosevelt bank holiday) for an issue of $\$ 1,500$ of scrip, to be used as soon as the State Printing House had sent the first 500 one-dollar certificates. The first unemployed men who expected to be paid in scrip went to work plastering a room at the County Farm. The following day the Atlantic City Council decided to ask for $\$ 1,000$ of the scrip to use for public work projects on the city's streets. ${ }^{70}$

It took over three weeks for the scrip certificates to arrive. The State Printing House evidently was not well prepared to meet the requirements of the Zylstra Act - further evidence of the rushed nature of the legislation. The News-Telegraph reported on March 16 that the printing would take place that day or the next; then that the certificates would arrive on March 21; then on March 28. They finally reached Atlantic on March 31, delayed by the difficulty of printing the stamps and finding an adhesive that would keep them affixed to the certificate. But once the scrip arrived, men could be set to work. Some of the

68. Decorah Journal, 6/6/1934; Sioux Center News (reporting an item in the Des Moines Register), 8/3/1933; Des Moines Register, 2/17/1934, 3/2/1934, 4/16/1934.

69. Atlantic News-Telegraph, 3/7/1933.

70. Atlantic News-Telegraph, 3/8/1933. 
first received $\$ 350$ in scrip, "mighty glad to get the work" to demolish the burnt-out courthouse. ${ }^{71}$

To provide an outlet for the scrip, and to prevent its piling up, the county treasurer acted as clearinghouse, standing ready to buy back unwanted scrip. An early sign that things were not going as well as had been hoped was that much of the scrip was channeled through the treasurer. One result was that the county, which had issued about $\$ 3,000$ of certificates by the end of April, vowed to hold off any further issue until the problem of the apparent glut had sorted itself out. That apparently happened, as the supervisors ordered another $\$ 2,500$ in scrip in mid-May. The Griswold town council asked for, and received, \$300 in scrip after funds from the RFC failed to materialize on time. Over the succeeding months, Cass County slowly placed about $\$ 1,000$ of the rest into circulation. In November, the county treasurer began to pay 20 percent of the salary of all county employees in scrip - a technique, unpopular with the recipients, learned from Polk County. In January 1934, when the Atlantic City Council applied for $\$ 500$ more in scrip, it was told that the board of supervisors had decided not to put out any new scrip until all the original issue, totaling $\$ 4,400$, had been redeemed. ${ }^{72}$

The Wilson bill gave Cass County a convenient way out of issuing more scrip, but in any case the need had passed. The county raised some money by selling redeemed scrip as souvenirs at $25 \$$ per certificate, but not as much as the $\$ 950$ the treasurer was hoping for. Final redemption was in June 1935. ${ }^{73}$

IRVING FISHER thought that stamp scrip should be of the type that Gesell had originally suggested: that a stamp should be required each week (or fortnight, or month), rather than with each transaction, which was Zylstra's approach. When Fisher heard that Zylstra's bill mandated transactions stamp scrip, he immediately had his research assistant, Hans Cohrssen, send a

71. Atlantic News-Telegraph, 3/16/1933, 3/20/1933; Griswold American, 4/5/1933.

72. Atlantic News-Telegraph, 4/29/1933, 1/10/1934; Griswold American, 5/31/1933; Des Moines Register, 11/2/1933.

73. Atlantic New-Telegraph, 11/7/1933; Minutes, Cass County Board of Supervisors, 6/10/1935. I am grateful to Phil Chinitz of Atlantic for this latter reference. 
telegram and letter to urge the use of the dated variety, but by the time the correspondence arrived, the bill had already passed.74 Although Rock Rapids, along with Mason City, required that a stamp be affixed if the scrip were idle for too long, only one town in Iowa adopted Fisher's approach from the outset.

Discussion of scrip in Red Oak (pop. 5,778 in 1930) began in early 1933, and the city issued its first scrip on March 11. Each dollar certificate had spaces for 52 two-cent stamps: "One stamp must be affixed each Wednesday at midnight by the holder of the certificate at that time, thus making Wednesday scrip transactions rapid and the scrip 'hot.'" 75

The first stamp was due at 12:01 a.m. on Wednesday, March 15 , so the scrip could circulate without cost for its first few days. In another innovation, farmers received a significant part of the scrip issue for their produce, giving them prices some 20 percent above those prevailing at the time. The foodstuffs so acquired would then be sold and the proceeds added to the fund to redeem the scrip.

As with most scrip plans, the initial reaction was enthusiastic. Merchants who had originally avoided signing up clamored to participate as the first scrip started circulating. The Chamber of Commerce agreed to purchase scrip (at a discount) if a merchant worried that he was getting too much of it. Not surprisingly, the threat of having to pay for a stamp on Wednesday generated a lot of business on Tuesdays, which was otherwise a slow day for merchants.

The initial large issue (of $\$ 750$ over three days - $\$ 559$ on the first day alone), however, led to some scrip indigestion and the hasty establishment of a clearinghouse committee to sort out the problem. "We discovered that many business men were not using discretion in the use of scrip," members of the committee

74. Cohrssen mentions this in his letter of February 28, 1933, to Charles H. Barber of Mason City (copy in the Lester Milligan Archives, Mason City Public Library, Mason City). Earl Dean, who represented Cerro Gordo County in the Iowa House, had mailed a copy of the text of Zylstra's bill to Fisher. The telegram and letter were dispatched on February 27, after the bill had already completed its stages in the House.

75. Red Oak Express, 2/23/1933. I am grateful to Rachel Clemens for transcribing some of the articles from the Red Oak Express referred to in this section. 
said. "The men were looking for a 'dumping ground' for stamp money and instead of distributing it equally in various places they unloaded it as soon as possible at the first opportunity." 76

By April, more problems surfaced, as merchants discovered that they were the ones who usually held most of the scrip come stamping time. The Chamber of Commerce endorsed a suggestion that merchants be allowed to give change for scrip if they wanted to and decided to call in $\$ 150$ of the issue. The problem was that a "lack of co-operation" by some of the businesses had "somewhat dimmed the scrip's real value"; the Chamber felt it necessary to point out that "scrip is not contaminating - it isn't a disease." 77

The scrip continued to be used through the summer, gradually becoming more and more of a nuisance, as real money began to appear and as more and more businesses threatened to stop accepting it. In October the Chamber of Commerce decided to retire the rest of the issue. If the stamp due on October $18 \mathrm{had}$ been affixed, the scrip could be turned in for redemption at face value over the following month, and people would then have the option of buying the redeemed scrip as a souvenir for 25 cents. The city had sold $\$ 374$ of stamps, leaving a shortfall of $\$ 176$ to redeem the $\$ 550$ then outstanding, but merchants quickly agreed to underwrite most of that. Souvenir sales probably raised the rest of the necessary funds, and a small amount of scrip ( $\$ 40$ or less) was never presented for redemption. ${ }^{78} \mathrm{Al}$ though Red Oak's experience with dated stamp scrip ended successfully, the fact that merchants wanted to opt out of the weekly game of musical chairs suggests that Fisher's dated stamp scrip was not without problems.

Perhaps the transaction and dated versions could be combined to good effect? The evidence suggests that such a hybrid was the most successful form of stamp scrip issued in Iowa. Rock Rapids's issue was small and successful. Mason City's much larger issue led to some scrip indigestion but ultimately achieved its aims.

76. Red Oak Express, 3/16/1933.

77. Red Oak Express, 4/6/1933.

78. Red Oak Express, 10/19/1933. 
ROCK RAPIDS (pop. 2,221 in 1930) was the first Iowa town to follow Hawarden's lead in issuing scrip. A delegation made the 45-mile trip to Hawarden in early November and reported back on the situation there. One thing was evident: to succeed, the plan required wholehearted cooperation and intelligent guidance. Regulation could not ensure success, which depended instead on the attitude of the townspeople. ${ }^{79}$

Instead of a one-dollar certificate requiring 36 three-cent stamps, Rock Rapids opted for an issue of 500 fifty-cent certificates, each requiring 54 one-cent stamps for redemption. An additional one-cent stamp had to be affixed if the scrip was unused for seven days, thereby producing perhaps the best version of stamp scrip - a hybrid between the transaction and dated varieties. The dated element meant that the issue would keep circulating and would accommodate $\$ 13,500$ of transactions in little more than a year. The rates of pay $-\$ 1.60$ for an eight-hour day, paid as one dollar in scrip and 60 cents in cash - were identical to those in Hawarden.

Demands for relief were smaller in Rock Rapids; initially, only 14 men were employed using the scrip. A newspaper editorial exhorted merchants to circulate it, and the city also expressed concerns that it was circulating too slowly. But the community seems to have gotten the message; in February the paper reported that it was moving at a good rate. The city had sold \$217 in stamps to that point, needing just \$33 more to be sold to pay for the redemption of the issue. On average, each certificate had received a new stamp every four days. ${ }^{80}$

As news of its success with stamp scrip got out, Rock Rapids began to receive delegations interested in copying its version of the plan. ${ }^{81}$ Even so, its plan was not without problems of its own. In a letter to Hans Cohrssen, W. F. Gingrich, the Rock Rapids superintendent of municipal public utilities and originator of the plan, wrote,

79. Lyon County Reporter, 11/10/1932.

80. Lyon County Reporter, 11/24/1932, 1/1/1933, 2/9/1933.

81. Officials from Luverne, Minnesota, visited in December. Although Luverne's mayor and council were in favor of adopting the plan, local merchants were not. See reports in the Rock County [Minnesota] Star, 12/2/1932 and 12/9/1932. 
The difficulties experienced are that people generally fail to get back of it as they should, in other words, when the merchant who first receives the scrip from the worker attempts to pass it out as change he finds that people generally are reluctant to accept it, therefore the merchant uses what he can among his own employees and turns the balance back to the city in payment for his electric light, heating and water bills, thus converting the scrip into cash which in turn must be paid out by the city as cash to the worker, thereby to some extent defeating the purpose of the scrip. ${ }^{82}$

But the scrip continued to circulate and started to come in for redemption; the first pieces were sold to Chase National Bank in New York, which was building a collection of scrip for display. The Lyon County Reporter claimed that the success of the plan seemed to be assured. 83

A snowstorm in late March gave scrip a last cheer, as Rock Rapids used it to pay workers to clear the streets.

The blizzard of Saturday and Sunday demonstrated the value of scrip in towns where money has been more or less scarce. Any community where the treasury has been depleted during these hard times would have hesitated before they put crews at work clearing away the drifts, not knowing where the money was to come from with which to pay the laborers. Here in Rock Rapids there was no hesitation. Crews were out early shoveling snow and making it possible for residents to get about during the day. Had the city been "broke," this would have been impossible. So the scrip plan helped in two ways. It put men to work who would otherwise have been idle and cleared the streets so they were passable. ${ }^{84}$

All in all, scrip served Rock Rapids well, and the town paid off all the scrip submitted for redemption by mid-1933, just as federal money started to arrive.

THE LARGEST of Iowa's municipal scrip issues was Mason City's (pop. 23,000 in 1930): 10,000 one-dollar certificates. The impetus came from Colonel Hanford MacNider, a former national commander of the American Legion and recently retired

82. W. F. Gingrich to Hans Cohrssen, 2/13/1933, Fisher Archives.

83. Lyon County Reporter, 3/16/1933.

84. Lyon County Leader, 3/23/1933. 
as U.S. Minister to Canada. Believing, as President Hoover had, in the virtues of cooperation and minimal government compulsion, MacNider found the idea of scrip appealing. The local Chamber of Commerce agreed, and in January 1933 established a subcommittee to investigate the feasibility of issuing scrip. The committee did its job carefully, sending letters to Irving Fisher and to Anaheim and Hawarden to get information on how scrip worked there. The upbeat replies the committee received encouraged it to proceed. ${ }^{85}$

Concurrently, there was a competition to find the best work projects. The local newspaper reported on many of the suggestions. Construction of new roads, and the diversion of old ones, were the favorite suggestions; others included the construction of a municipal swimming pool and using the money to subsidize wages, with the aim of attracting new business to the town. ${ }^{86}$ The committee's report spelled out the need for a clearinghouse mechanism. It also estimated that a $\$ 10,000$ issue would represent about 5 percent of the city's business if each one-dollar certificate turned over once per week. ${ }^{87}$

Mason City refused to be rushed into issuing scrip. In the end, it was not placed into circulation until May, and great care was taken to try to avoid what its promoters saw as errors in other plans elsewhere. The one-dollar certificates required that a two-cent stamp be attached each Wednesday and for every transaction, thus speeding up circulation without causing a "musical chairs" effect. The net result was that the scrip turned over twice per week on average, increasing local business by $\$ 20,000$ per week. Some of the transactions were paying old bills: with cash, it makes sense to delay payment; with scrip, it makes sense to pay bills when there is a need to put on a stamp, so some bills were settled even before they became due.

85. Report on the Mason City scrip plan, undated typescript (written while it was still in operation), Milligan Archives; conversation with Terry Harrison, archivist in Mason City, August 2004. For MacNider's views, see also Mason City Globe-Gazette, 2/22/1933 and 3/22/1933.

86. Mason City Globe-Gazette, beginning 1/19/1933. The column ran almost daily for a month, producing more than 20 different suggestions.

87. Mason City Globe-Gazette, 2/22/1933. 
Most of the town's 400 merchants agreed to accept the scrip and pledged that, if necessary, they would pay for the issue's redemption; in fact, the pledges backed the issue twice over. The committee overseeing the issue used one of the town's banks as a clearinghouse, which bought up scrip from those who had too much and (a harder job) sold it on to those who had little but who were willing to use it. 88

An average of 25 men were employed three days per week (to spread the benefits to as many as possible) and were paid 30 cents per hour in scrip. ${ }^{89}$ Ultimately, the city chose a road-building project because of its potential to benefit the city's businesses. "Mason City was frankly selfish in constructing this experimental type of road for a lot of her employment depends upon cement, sand, and gravel and if it can be promoted as a surface for secondary and lighter travelled roads, it will help employment in Mason City through the stimulation or the sale of Mason City products." 90

The project initially seemed very successful: the city issued the last of the $\$ 10,000$ in scrip on July 8 . As it required 52 stamps for redemption, this meant that all of the issue would complete its rounds and be ready for redemption by July 1934. Holders of a completely stamped certificate had a month to turn it in for redemption; so August 7, 1934, would theoretically see Mason City scrip-free. "It is an interesting experiment that will go down in history as one of the features of the 'great depression.' A good deal of the scrip is already being picked up by collectors and it is thought probable that the value of that outstanding will amount to considerably more than $\$ 1.00$ shortly after the issue is out of circulation." 91

But appearances were deceptive. Lester Milligan, secretary of the Chamber of Commerce, writing soon after the project was completed, produced a more skeptical report. The scrip did not

88. Mason City Globe-Gazette, 3/23/1933.

89. Mason City Globe-Gazette, 4/20/1933.

90. Lester Milligan, undated typescript report, Milligan Archives. The road is still known as the Scrip Road and is still used, but is now in desperate need of repairs. See Elvins, "Scrip Money and Slump Cures," 235; and Mason City Globe-Gazette, 10/29/2010.

91. Milligan, undated typescript report, p.3, Milligan Archives. 
come in for redemption as quickly as expected. Most scrip transactions were concentrated with just a few merchants: "Professional men and others seldom, if ever, saw it. A few stores got more than their fair share." As a result,

It became necessary to establish a clearing house. The scrip committee each week bought up from various firms the excess over what they could put into circulation through payment of their own bills. Some loyal firms, including one large manufacturer, agreed to purchase it from the clearing house twice each month and start it going again through payrolls and other bills. But ... the scrip would have met its Waterloo ... had not the Board of Education come to bat and bought enough to pay the school teachers ten percent of their salaries..$^{92}$

In the end, community loyalty brought the project to a successful conclusion, despite bookkeepers who "cursed and raved" and "blamed all of their mistakes on scrip." People often evaded the requirement to put a stamp on the certificate each time it was used (opting instead to put on just one per week), and stamps that had been attached often fell off. As a result,

It was not until August, one year and thirty days after date of the last issue that the game was finished. And no one wanted to play again. It had proven through experience that the stuff would not circulate rapidly. Its circulation had been limited, proven by the fact that 49 firms bought and paid for $\$ 6,966.00$ of the $\$ 10,620.22$ worth of stamps sold. Not only did they pay the penalty, but so did their employees who took regularly from ten to twenty-five per cent of their payrolls in scrip and, of course, paid a correspondingly heavy tax for stamps. Most of the community never saw it and carried no share of the burden. And it was a general nuisance, provocative of argument and ill feeling between buyer and seller, and of errors in bookkeeping and accounting. ${ }^{93}$

And yet, after all the arm-twisting, the plan was successful in achieving its stated aims. Despite the unequal burden placed on

92. Lester Milligan, "The Stamp Scrip Experience of Mason City, Iowa," in Mitchell and Shafer, Standard Catalog of Depression Scrip, 311-13. Although there was no cost to the holder to keep the scrip until the next stamping date, optimists had estimated that the scrip would be used more often - and so acquire stamps more rapidly.

93. Ibid. 
those 49 firms, the project was able to close its books showing no net cost to the city. With over $\$ 500,000$ worth of business done with the scrip, the unemployed were put to work and the city got its new demonstration concrete road. None of the merchants had to hand over any of the money they had guaranteed, and the whole thing even made a $\$ 300$ profit for the city. ${ }^{94}$

STAMP SCRIP had had its day. Born out of the hopelessness and despair of the Great Depression, it had provided useful emergency relief in several small towns and a boost to the political career of Charles Zylstra. But the problems of congestion, indigestion, and lukewarm support soon became apparent elsewhere, so few mourned its demise. When Senator George Wilson proposed his bill to redeem the county scrip, Merle Stone, the editor of the Hawarden Independent and Zylstra's nemesis, exulted. His article, "Stamp Money On Its Way Out," included the subheading "Iowa Senate Passes Bill Consigning Zylstra Law to Scrap Heap." When news of the size of the bond issue in Polk County became known, Stone reprinted his February 1933 editorial along with a long quotation from the Des Moines Register on Polk County's negative scrip experience. When Zylstra wrote in to defend himself and complained that the Independent misrepresented him, Stone was scathing.

Mr. Zylstra complains that The Independent "won't print anything pertaining to the possibilities [of the scrip plan] ..." Ye gods! Back in 1932 when Mr. Zylstra first began to run for public office and was seeking an inexpensive (to him) form of publicity, this newspaper printed column after column of his contributions relating to his scrip plan. Since then we have given space to various other contributions from him and then because last week chose to present only a part of his lengthy contribution, he gives evidence of feeling aggrieved. It's really too bad.

And now Charley wants us to spell him in the task of "saving the country," but owing to the necessity of being compelled to de-

94. “Statement of Mason City's \$10,000.00 Scrip Fund," 8/13/1934, Milligan Archives. 
vote so much of our energy toward the difficult task of earning a living we fell compelled to decline the assignment. ${ }^{95}$

But it was not just Stone's vendetta against Zylstra that led to the conclusion that stamp scrip's day was past. There was general agreement that scrip had run its course. The New York Times, in its review of the first year of the New Deal, commented,

A year ago, somebody had the idea that in the absence of regular money local scrip might serve a useful purpose. This was to be self-liquidating through the medium of stamps to be affixed each time it changed hands.

Only six [sic] counties tried out the plan and now wish they hadn't. Local merchants did not care much for it and they cared even less to affix the redemption stamps. Now it is found that there is little money in the treasuries with which to redeem the issues.

As a result it has become necessary to issue bonds for the sums necessary to redeem outstanding scrip. ${ }^{96}$

The experiment had run its course, and had been found largely wanting.

Although scrip had demonstrated its advantages in Hawarden and certain other small towns in Iowa, using it in large cities and at the county level seemed to be a step too far. Merchants and customers in a small town might be prepared to put up with the inconvenience and cost of using scrip for the greater good, to benefit their neighbors, and to accomplish city improvements, but this community spirit was available only in a more diluted form in larger areas. Merchants found that the most effective way of disposing of the scrip was to wait until they had \$25 worth of it and then cash it through the banks. Although this involved the loss of 4 percent of the value, they were still prepared to use scrip as it did appear to generate new business. But as scrip was recirculated in county employees' salaries, displacing cash, it became clearer that, after the initial boost, the merchants could expect no great increase in trade while still having to bear the brunt of the costs.

95. Hawarden Independent, 1/4/1934, 5/17/1934, 8/30/1934. In subsequent years, the Independent pounced on - and editorialized on - any perceived wrongdoing by "Charley."

96. New York Times, 3/4/1934. 
As the "first mover" to attract widespread national attention, Hawarden's plan, by its mere existence, generated business for the town as visitors came to see what was happening. Those people spent real money at Hawarden shops, restaurants, filling stations, and perhaps at the local hotels, thus boosting the local economy. Many no doubt took away a piece of scrip as a souvenir. But as other cities and counties began to issue scrip, the novelty wore off and souvenir purchases were lower.

The easier it was to dispose of scrip, the more likely it was that the project would be successful. Winneshiek County's innovation allowing businesses to cash scrip directly at the county treasurer's office helped in this respect, as it provided an alternative outlet to the banks. ${ }^{97}$ In addition, the one-dollar value of the certificate, about four hours' pay at the minimum wage mandated by the Zylstra Act, was perhaps too big a denomination to pass easily, especially as retailers were not required to give change. 98 Rock Rapids, Albia, and Appanoose County were wise to issue 50-cent certificates that required just one-cent stamps, producing an easier medium to use.

The timing of the stamp scrip saga is significant, too. Had the idea of stamp scrip been around a year or two earlier, there would have been less threat to its viability posed by the various funds that started to flow in from the federal government under New Deal programs. If real money were available, why would anyone want to use stamp scrip, except at a hefty discount? But in the absence of real money, scrip could form a reasonable short-term substitute when the plan was carefully designed and well executed.

Unfortunately, the ability of communities to digest scrip turned out to be less than the one dollar per person Zylstra thought would work. Winneshiek County's issue of $\$ 6,000$ was enough to cause indigestion in a county of 22,000 people. Perhaps the maximum issue should have been limited to something closer to 25 cents per person. But then the sums available would have been too small to make a significant difference to the unemployment and poor relief problems.

97. Decorah Journal, 4/19/1933.

98. Very roughly, a dollar in 1932 would buy as much as $\$ 16-\$ 18$ today. 
Roosevelt's declaration of a bank holiday might have encouraged city councils and county boards to look with more favor on the possibility of scrip. But in small towns, shops and stores were able to extend credit or to accept checks drawn on closed banks for later cashing, and in large cities clearinghouse scrip performed well for the few days or weeks for which it was required.

Stamp scrip died in Iowa with the end of Pella's program in 1937, some three years after the New York Times had written scrip's obituary. The Zylstra Act had been experimental, an emergency measure with a two-year life, and there was no thought to extend it. Zylstra himself entered the 1934 gubernatorial race as a Democratic candidate but came in third out of four in the primary in June. He received little press attention, even in Hawarden. He left Iowa in the early 1940s and died in Chicago in 1946. ${ }^{99}$

Occasionally, stamp scrip is mentioned today. A number of local currencies in Germany are based on Gesell's original dated stamp scrip idea, as is England's Stroud Pound. It has been suggested as a possible weapon to combat deflation - when prices are falling, why not make the money fall in value with them? but to date no one has used scrip in this way. Anyone seeking to do so would be well advised to examine carefully the results of the Iowa experiments. For a plan to have any chance of success, there must, at a minimum, be widespread local support, a clearinghouse arrangement for businesses to dispose of surplus scrip, relatively small denominations (nothing larger than $\$ 5$ and $\$ 10$ certificates at today's prices), and a requirement that the stamp be added for each transaction, or on a particular date, whichever comes first.

99. See obituaries in the Hawarden Independent, 12/5/1946, and the Sioux Center News, 12/12/1946. 